\title{
Auttaako Arkiähky arjen ähkyyn?
}

Jussi T. Koski (2008). Arkiähky. Taudinkuvaa\&ajankuvaa. Kirjapaja.

J ussi T. Koski aloittaa kirjansa toteamalla, ettei hän aio varsinaisesti määritellä otsikon arkiähkykäsitettä. Kyseessä on hänen mukaansa huokoinen käsite, joka ei luonteeltaan ole tarkoin määriteltävissä. Tämä on erittäin hyvä, lupaava ja täsmällinen lähtökohta kirjalle, sillä sama tilannehan koskee monia muitakin mielenkiintoisia ja tärkeitä käsitteitä. Käsitteen määrittelemisen vaatimus on usein pakollista, ulkoa opittua liturgiaa, joka pikemmin estää asian todellista jäsentämistä kuin edistää sitä.

Mutta jollain tavalla käsitteitä on hahmotettava, myös tällaista uutta ja näköjään hyvin tietoisesti lanseerattavaa käsitettä. Käsite voi olla tarkoituksellisesti moniselitteinen ja ristiriitainen, eikä tässä ole välttämättä mitään negatiivista. Sellainen käsite voi toimia nimenomaan virikkeenä, joka haastaa lukijan tai vastaanottajan pohtimaan itse.

Kosken käsiteluomus näyttäisi sisältävän ristiriitaisen suhteen arkeen. Alussa on voimakas ylistys: arki on se, jossa kaikki loppujen lopuksi olennainen tapahtuu ja jossa asiat ratkaistaan. Toisaalta arki on erilaista rutinoitumista ja sinänsä täysin epäolennaisiin pikkuongelmiin sotkeutumista. Arkiähky kumpuaa siis siitä, että ihminen tuskastuu arkipäivän ongelmiin ja haluaa jotain toisenlaista, mutta samalla on suorastaan intohimoisesti arjessa kiinni ja tajuaa, että sille ei loppujen lopuksi ole vaihtoehtoa.
Kosken kirjoittamistapa on linjassa sen kanssa, miten hän suhtautuu aiheeseensa ja luomaansa käsitteeseen. Myös kirjoittaminen on huokoista, monessakin mielessä. Siinä on ilmaa, särmiä ja ristiriitaisuuksiakin. Koski on aiemmissakin teoksissaan kokeillut tietokirjoittamisen perinteisiä rajoja, ja tämä linja jatkuu. Pohtivan ja paljolti jutustelevan perustekstin lomaan mahtuu monenlaista tavaraa, aforistisia kiteytyksiä, puhdasta kielellistä leikittelyä, itseironisia dialogeja ja ylipäätään monenlaisia tekstikatkelmia. Ajoittain teksti on hyvin tajunnanvirtamaista, ajoittain hyvin tavallista asiaproosaa. Esipuhe tulee vastaan vasta pitkällä matkan varrella jaa loppumatkasta lukija kohtaa vielä useita muitakin esipuheita tai niiden luonnoksia eri versioissaan. Kielellä ilottelun mehukasta antia on esimerkiksi pitkä luettelo, joka koostuu pelkästään erilaisista yhteiskunta-loppuisista yhdyssanoista kuten Innovaatioyhteiskunta, Kerää leimoja- yhteiskunta jumiyhteiskunta, jumiyhteiskunta, jumiyhteiskunta ja niin edelleen.

Itse asiassa tätä toisentyyppistä materiaalia, leikittelyä ja kokeilua olisi saanut olla enemmänkin, se on tässä kirjassa mieleen jäävää antia. Taitavaa on myös tapa, jolla aiemman infoähky-kirjan ainesta tuodaan esille uudessa yhteydessä. Samalla kirja kuitenkin osoittaa, ettei pelkkä hupailu tai rajojen rikkominen sinänsä olisi pitkän päälle kovin kiinnostavaa, ellei siihen sittenkin yhdy vankkaa ja vahvaa asiantuntemusta. Myös kirjoittamisen helppous on mahdollista vain silloin kun tuntee asiansa ja Koski tuntee maailman, josta hän kirjoittaa, asiantuntijaorganisaatiot, kokoukset ja kaiken sen touhun. Teoreettisena taustana taas tulee esiin 1900-luvun filosofian suuri klassikko HansGeorg Gadamer.

\section{Älyttömiä käyttöohjeita}

Luovan työn suhde arkipäivän pikkuseikkojen järjestämiseen on kirjan varsinaista ydintä. Arkipäivä taas tarkoittaa tappelua digivastaanottimen virittämisen kanssa ja muita samanlaisia pieniä asioita, joista elämässä ja myös tässä kirjassa helposti nousee mahdottoman suuri numero. Esimerkit käännösohjelmien tarjoamista absurdeista käyttöohjeista, kännykkäoperaattorien tarjouksista ja muista tämän päivän kummallisuuksista ovat aitoja ja osuvia, sellaisiin on vaikea olla törmäämättä. Tarinat tarjoavat samaistumisen mahdollisuuden, mutta juuri tuttuuden vuoksi nämä ehkä vähän narsistisestikin kerrotut tarinat vähitellen menettävät mielenkiintonsa. Jää miettimään, mitä kirja sittenkään saa mielenkiintoisista aineksistaan irti.

Kosken eräs keino arjesta selviytymiseen on äärimmäinen rationalisointi: kun ostaa monet lenkkitossut kerralla, tarvitsee ostaa niitä harvemmin ja aika säästyy luovempaan työhön. Tässä on jotain ristiriitaista: arjen rutiineista ollaan toisaalta viehättyneitä, mutta sitten ne 
kuitenkin pitäisi ylemmyydentuntoisesti hoitaa pois mahdollisimman helposti. Lenkkitossuesimerkki ei ole edes kovin edustava sikäli, että kirjan perusteella arki ja sen ongelmat ovat voittopuolisesti erilaisten teknisten laitteiden kanssa näpräämistä ja tekniikan arkisiin ongelmiin törmäilyä. Ja tottahan on, että tekniikan kummallisuudet säätelevät arkipäiväämme hyvin paljon, mutta sittenkin tällainen näkökulma arkeen on oikeastaan aika kapea.

Tärkeä keino on myös huumori. Kirja tarjoaa paljon luovia oivalluksia arkipäivästä ja sen kielestä. Koski leikkii mielellään sanoilla ja pystyy käyttämään hyväksi kaikenlaista sattumoisin eteen tulevaa materiaalia. Ehkäpä arjen kiireen tuottamasta ähkystä selviääkin juuri sillä, että ei ota sitä liian vakavasti vaan näkee sen absurdiuden. Eihän arjesta selviytymiseen mitään varsinaista reseptiä voi ollakaan, sitä on vain elettävä.

\section{Sivistys ja arki}

Silti kirjasta jää kaipaamaan jotain enemmän. Koski tuo Gada- merin esille tyylikkäästi, ilman minkäänlaista filosofisilla termeillä keikarointia. Hän ei yritä esittää mitään varsinaista teoriaa, jota sitten jotenkin sovellettaisiin arkipäivään. Sen sijaan hän muistuttaa, että meillä on myös sivistystä korostava perinne, joka voisi tarjota syvyyttä ja pysähtymisen mahdollisuutta arkipäivän latteuksien ja turhan höösäämisen keskellä. Koski esittää purevia huomiota pintakulttuurista, jossa kaikki latistuu samanlaiseksi kiireiseksi mössöksi. Hän muistuttaa pysähtymisen, harkinnan, terveen järjen, kuuntelemisen ja aidon läsnäolon tarpeellisuudesta Kritiikin ja sopeutumisen suhde jää kuitenkin askarruttamaan - tarvitaanko pysähtymistä sittenkin vain siksi menestyttäisiin vielä paremmin?

Arkiähky jää loppuun saakka ristiriitaiseksi ideaksi - mikä näyttää olleen tarkoituskin. Kirja on taitavasti rakennettu, mutta erityisen klassikon aineksia siinä ei taida olla. Erilaista materiaalia ja inspiroivia ideoita on, mutta ehyempää näkemystä tai linjaa jään itse kaipaamaan.
Aivan lopussa Koski itsekin pohtii jonkinlaisen ohjelmanjulistuksen tai luovien ihmisten luokan yhteisen linjan tarpeellisuutta. Ja löytää sen vaatimuksesta, että kauppojen on oltava aina auki.

Vaatimus tuntuu olevan täysin ristiriidassa esimerkiksi Gadamerin edustaman, perinteitä, eroja ja vivahteita kunnioittavan ajattelun kanssa. Kun toisaalla neuvotaan, että välillä on syytä olla pois verkosta ja katkaista info- ja arkiähkyä tuottava kommunikaatio, niin miksemme voi tehdä jotain myös kauppaähkylle? Jos kerran tekniikan hölmöyksiinkin loppujen lopuksi pitää sopeutua, niin miksei voi reilusti myöntää, että kaupat voivat ja niiden itse asiassa pitäisikin olla välillä myös kiinni?

Arjen ja pyhän eron lopullinen tuhoaminen, kaiken alistaminen kaupassakäynnille, sehän juuri on arkipäivän tuhoamista. Sillä tavoin kaikesta ajasta tulee samanlaista mössöä, mitä kirja itse toisaalla ankarasti arvostelee.

\section{Eero Ojanen}

